\title{
PROTEÇÃO DO PATRIMÔNIO HISTÓRICO, CULTURAL E ARTÍSTICO E O INSTITUTO DO TOMBAMENTO
}

\author{
Etiene Maria Bosco Breviglieri ${ }^{1}$ \\ Matheus Carvalho Assumpção de Lima ${ }^{2}$
}

\begin{abstract}
Resumo
A tutela do patrimônio histórico, cultural e artístico é de fundamental importância para a coletividade e para as gerações futuras, visto que permite que as histórias e experiências culturais perpetuem-se no tempo, servindo-nos de alicerce na construção do presente, sem necessidade de restaurar o passado. Sob esse prisma, vê-se que não incumbe somente ao judiciário ou legislativo cuidar da temática, mas também a sociedade, em colaboração com o poder público, como insculpido na Constituição Federal. O tema mostra sua relevância quando contrastado com outros institutos de relevo constitucional, tal como a propriedade, que é mitigada frente à história a ser salvaguardada. Assim, é imprescindível discorrer sobre os aspectos históricos e conceituais perpassados pela temática, iniciando-se com o direito comparado, especialmente o português e francês, haja vista as revoluções burguesas que inauguraram a tutela jurisdicional da história. Igualmente, necessária a realização de uma análise dos princípios administrativos norteadores do tombamento, vez que são normas elementares da ciência jurídica, alicerçando-a na construção dos demais institutos. Ademais, fundamental a análise das formas de atuação do Ministério Público e demais órgãos da administração pública, bem como das minúcias do processo de tombamento, a fim de obter uma análise crítica e ponderada do tema.
\end{abstract}

Palavras-chave: Tombamento; Patrimônio histórico; Tutela Jurisdicional; Decreto Lei 25/37; Mecanismos de Proteção.

\section{INTRODUÇÃO}

Historicamente o Brasil é um país de abastadas riquezas paisagísticas, e, por que não dizer, arquitetônicas, visto que antes mesmo da desbravada colonização lusitana, nos ora longínquos territórios tupiniquins, os nativos, estimados em 2 milhões de pessoas ${ }^{3}$, dividiam-se socialmente em tribos, cada quais com diferentes características históricas, cânticos, culturas e religiões, além de técnicas peculiares e estandardizadas de caça, pesca e agricultura.

\footnotetext{
${ }^{1}$ Pós-doutora pela Università degli Studi di Messina, na área de Responsabilidade Civil. Professora efetiva e com dedicação exclusiva na UEMS Universidade do Estado de Mato Grosso do Sul, Campus de Paranaíba. E-mail: etienebosco@gmail.com ${ }^{2}$ Graduação em Direito pela Universidade do Estado de Minas Gerais (UEMG) - Campus de Frutal/MG. E-mail: m_acal@hotmail.com

${ }^{3}$ IBGE. Instituto Brasileiro de Geografia e Estatística. Brasil: 500 anos de povoamento. Rio de Janeiro. 2000. Disponível em: <http://brasil500anos.ibge.gov.br/territorio-brasileiro-e-povoamento/historia-indigena/os-numeros-da-populacao-indigena>. Acesso em: 01/09/14.
} 
Nessa toada, é certo que com os primeiros contatos entre os nativos e os portugueses houve abundante troca cultural. No entanto, imbuídos pelo sentimento explorador, os colonizadores utilizaram-se de violência e repressão à cultura indígena, que permaneceu eloquentemente silente.

Em consequência disso, houve a imposição da cultura europeia, influenciada pelo catolicismo, que estava arraigado às colonizações do século XIV, o que culminou com a construção de igrejas, e com a adoração de imagens bíblicas, as quais se tornaram parte da cultura brasileira com o perpassar das décadas e permanecem até os dias atuais como uma das grandes formas de expressão cultural, consoante se verifica no Estado de Minas Gerais, conhecido pela exuberância de suas igrejas.

Contudo, denota-se que em ambos os momentos históricos não houve qualquer preocupação com a preservação da cultura indígena e/ou da cultura europeia, seja pela falta por fatores ético-sociais ou por influência do sistema jurídico já vigente em Portugal, que contava com o arquivo de bens históricos instalados no "Castelo de São Jorge", popularmente denominado "Torre do Tombo", no período de 1378 a $1755^{4}$. Sistema jurídico esse adotado pelo Brasil, como modelo para a formação do atual processo de tombamento.

Sob este prisma, seguindo o legado europeu, especialmente o português, iniciado durante as revoluções sociais, o moroso ordenamento jurídico brasileiro introduziu embrionariamente ideais protecionistas, sem, contudo, força cogente necessária à conservação dos bens que paulatinamente se esvaiam no tempo.

Com o passar dos anos o legislador brasileiro passou a se preocupar com a permanência da identidade histórica e cultural do povo brasileiro, preocupando-se, ainda, com a herança do passado conjugada com o presente, o que culminou com a edição e promulgação do Decreto-Lei $n^{\circ} 25 / 37$, ainda sob a égide da Constituição Federal de 1937, considerada o grande marco para a preservação da história, paisagem e cultura nativa, rompendo com o descaso do poder estatal com a relevância destes bens, advindo da colonização Portuguesa de exploração e seus resquícios.

Diante disso, vê-se que o presente estudo objetiva primordialmente a elaboração de um minudente e sistemático estudo sobre a evolução histórica e jurídica do patrimônio histórico, cultural e artístico, a luz do direito constitucional e infraconstitucional brasileiro, haja vista a relevância salutar da preservação temporal dos bens de referência social, como forma de salvaguardar as experiências vivenciadas em determinada época, perpassando-o de forma intergeracional.

Convém notar, outrossim, que o presente estudo tem por escopo a realização de uma profunda análise dos mecanismos jurisdicionais disponibilizados pelo legislador como forma de tutela dos bens históricos e culturais. Em consequência disso, analisar-se-á quanto à legitimidade ativa desses mecanismos de tutela.

\footnotetext{
${ }^{4}$ RIO GRANDE DO SUL. Instituto do Patrimônio Histórico e Artístico do Estado (IPHAE). O significado da palavra tombamento. Disponível em: <http://www.iphae.rs.gov.br/Main.php?do=noticiasDetalhesAc\&item=37302>. Acesso em: 02/09/14.
} 
Sobreleva notar também, que neste trabalho tratar-se-á dos precedentes históricos do processo de tombamento não apenas no Brasil, mas em sistemas jurídicos análogos. Conseguintemente, serão apreciados os princípios administrativos aplicáveis ao tombamento, especialmente os princípios da supremacia do interesse público, da moralidade, da legalidade e eficiência.

Por seu turno, abordará os mecanismos jurisdicionais utilizados na proteção do patrimônio histórico cultural, bem como os órgãos legitimados para a tutela desses bens. Demais disso, aprofundar-se-á os conhecimentos inerentes ao Decreto-Lei n²5/37, a Ação Civil Pública proposta pelo Ministério Público, além dos estímulos fiscais existentes no sistema jurídico como forma de incentivo à proteção e conservação dos bens de relevante valor para a sociedade.

\section{OS PRECEDENTES HISTÓRICOS DO TOMBAMENTO E SEUS PRINCÍPIOS ADMINISTRATIVOS}

A princípio, antes de ingressar nos aspectos jurídico-legais e doutrinários da intervenção estatal na propriedade privada, é fundamental trazer a lume a conceituação histórico-jurídica do vocábulo tombamento.

Nesse lume, verifica-se que da expressão "tombar" provém do direito lusitano e significa o processo de registro, inventário e inscrição dos bens móveis e imóveis no livro do tombo, ao argumento de que tais bens estão umbilicalmente atrelados a fatos históricos, arqueológicos ou artísticos, o que os torna inolvidáveis para a população e para o Estado, consoante preceituado pela doutrina administrativista mais abalizada:

Empregando o vocábulo tombamento, o direito brasileiro seguiu a tradição do direito português, que utiliza a palavra tombar no sentido de registrar, inventariar, inscrever nos arquivos do Reino, guardados na Torre do Tombo. ${ }^{5}$

Nessa vereda, decorrida a conceituação lato sensu, importante discorrer quanto à intervenção do poder estatal na propriedade particular de forma abstrata e subjetiva, vez que se trata de gênero do qual o tombamento é espécie. Para tanto imperativo descrever, ainda que suscintamente, a evolução histórica da propriedade, tanto de forma global, como também no sistema jurídico pátrio, utilizando-se, pois, de conceitos de cunho constitucional e civilista.

Historicamente, a propriedade constituiu verdadeiro direito natural, sendo erigida a direito fundamental nas declarações de direito da época do constitucionalismo. As tendências socializantes, porém, alteraram a fisionomia da propriedade, e de muitos ordenamentos jurídicos firmando o postulado ortodoxo de que a propriedade tinha caráter provisório até que chegasse à coletividade em massa. ${ }^{6}$

Posto isso, salienta-se que no início do século XX, precisamente em 1919, promulga-se na Alemanha, como fruto da primeira guerra mundial, a Constituição de Weimar, a qual possui como característica primordial a

\footnotetext{
${ }^{5}$ MEIRELLES, Hely Lopes apud PIETRO, Maria Sylvia Zanella Di. Direito Administrativo. 24. ed. São Paulo: Atlas, 201 1, p.63.

${ }^{6}$ PINTO FERREIRA apud CARVALHO FILHO. Manual de Direito Administrativo, 24. ed. Rio de Janeiro: Lúmen Juris, 2011, p.712.
} 
supremacia dos direitos sociais, consagrado pela necessidade da intervenção do Estado em diversos âmbitos (público e privado), como por exemplo na intercessão estatal nas relações contratuais de mercado.

Por tais razões, a propriedade, outrora vislumbrada apenas de forma concentrada, passou ter maior abrangência jurídica, ou seja, os conceitos foram substancialmente dilatados e passaram abranger também os valores patrimoniais, resultantes das relações privadas e/ou públicas.

Alicerçada nesse contexto, Carta Política de 1988 distendeu tratamento ímpar do direito à propriedade, trazendo ideais concomitantemente difusos e garantistas/protecionistas, tornando a propriedade um direito individual e de cunho privado, consoante carreado no artigo $5^{\circ}$, incisos XXII e XXIII da Magna Carta conforme assevera Ribeiro (2012):

O conceito constitucional de propriedade é mais lato do que aquele de que se serve o direito privado. É que do ponto de vista da Lei Maior tornou-se necessário estender a mesma proteção, que, no início, só se conferia à relação do homem com as coisas, à titularidade da exploração de inventos e criações artísticas de obras literárias e até mesmo a direitos em geral que hoje não são à medida que haja uma devida indenização de sua expressão econômica. ${ }^{7}$

Oportuno gizar que na conceituação jurídica o termo propriedade perpassou por diversas etapas histórico-evolutivas, o que culminou também com a mutação do conceito de função social, o que acarretou o abandono da ideia de similitude entre o conceito de propriedade lato sensu e doutrina civilista. ${ }^{8}$

Desta forma, observa-se contemporaneamente que Código Civil de 2002 não definiu juridicamente a propriedade, enunciando exclusivamente quanto suas características e poderes inerentes a seu proprietário.

A par disso, coube à doutrina definir o termo como sendo "o poder assegurado pelo grupo social à utilização dos bens da vida psíquica e moral", segundo Beviláqua. ${ }^{9}$

Perpassados os aspectos conceituais da propriedade à luz da constituinte alemã e do Código Civil, passase abordar as características concernentes a patrimônio histórico, cultural e artístico propriamente dito, e do tombamento, sob a ótica das constituições predecessoras a Lex Legum de 1988.

A esse respeito, infere-se que a concepção do tombamento, como instrumento jurídico destinado a proteção de bens materiais e imateriais, não se originou no direito pátrio.

Como se sabe, o tombamento é o primeiro instrumento jurídico de proteção do patrimônio cultural instituído no Brasil. Porém, a trama de direitos e obrigações que o caracterizam não é criação genuína do Direito pátrio, tendo sido institucionalizada como repercussão de uma tendência que se consolidou a partir da Revolução Francesa e da Revolução Industrial. ${ }^{10}$

Conquanto subsistam registros esparsos de preservação do patrimônio histórico e cultural em tempos longínquos, o marco histórico da positivação e preocupação com a conservação da cultura ocorreu após as

\footnotetext{
${ }^{7}$ RIBEIRO, Celso Bastos; MARTINS, Ives Gandra apud MENDES, Gilmar Ferreira; BRANCO, Gustavo Gonet. Curso de Direito Constitucional. 7.ed. São Paulo: Saraiva, 2012, p.418.

${ }^{8}$ MENDES, Gilmar Ferreira; BRANCO, Gustavo Gonet. Curso de Direito Constitucional. 7.ed. São Paulo: Saraiva, 2012, p.418.

${ }^{9}$ BEVILÁQUA, Clovis apud PEREIRA Caio Mário da Silva. Instituições de Direito Civil, Direitos Reais. 21. ed. Rio de Janeiro: Forense, vol. IV, 2012, p.75.

${ }^{10}$ ZANDONADE, Adriana. O Tombamento à Luz da Constituição Federal de 1988. São Paulo: Malheiros, 2012, p.19.
} vol.10, nº. 01, Rio de Janeiro, 2017.pp.95-126 
revoluções Francesa (1789) e Industrial Europeia (1780), visto que nesse interregno diversos elementos ideológicos forma dizimados, o que determinou a preservação dos monumentos símbolos da revolução.

Com efeito, posteriormente ao início das revoluções sociais, insurgidas contra o poder feudal e aristocrático e, em consequência dos ideais iluministas enraizados nos movimentos revolucionários, surge por meio da Assembleia Constituinte Francesa a primeira norma protecionista positivada.

A despeito disso, a Constituinte Francesa possuía como escopo, em breves relatos, "colocar os bens do Clero à disposição da nação, entendendo a medida, sucessivamente, aos bens nobres emigrados e da Coroa" ${ }^{\prime 1}$, além de confiscar os bens pertencentes aos senhores feudais e aristocratas no intuito de suprir o déficit econômico gerado pela revolução. Continuamente, tais bens foram afetados ao poder estatal e receberam a denominação de "patrimônio nacional", os quais foram caracterizados como "herança" da Nação Francesa".

No entanto, em decorrência da crise econômica que assoou a França no citado período, haja vista os exacerbados gastos com a revolução, o governo francês relegou a proteção histórica, artística e cultural, motivo pelo qual os monumentos passaram a ser destruídos e/ou empreendidos em interesses militares.

Do mesmo modo, depreende-se que finda a tomada do poder, como forma de represália as instituições monárquicas, o Estado Revolucionário, promoveu a destruição dos bens que lhes pertenciam, visando romper completamente com a simbologia representativa destes, cessando momentaneamente com as ideologias de proteção anteriormente lançadas, que se tornaram excepcionais.

Além disso, a eclosão da Revolução Industrial e a adoção de processos mecanizados como método produtivo, bem como a priorização do solo em detrimento das edificações restou absolutamente consolidada a ideia de devastação das referências culturais "cuja conservação se tornou objeto de negligência e cedeu espaço à especulação imobiliária”. ${ }^{12}$

A negligência com o patrimônio histórico Europeu perdurou até os idos do século XIX, quando surge o dramaturgo Victor-Marie Hugo como maior expoente e defensor dos bens considerados insubstituíveis e suscetíveis de perdas irreparáveis

O dramaturgo passou a utilizar de artigos e periódicos como forma de difundir os ideais de proteção das riquezas históricas, artísticas, arqueológicas e culturais da França.

Na mesma linha, em 1830, o historiador François Guizot, na condição de Ministro do Interior da França, encaminhou ao Rei Louis-Phillipe um relatório no qual sustentava que a civilização francesa era admirada na Europa em razão da riqueza dos monumentos que cobriam seu território, destacando sua importância para a História e para a Arte. ${ }^{13}$

Concomitantemente aos movimentos protecionistas, o governo francês deu provimento e institucionalizou o cargo de Inspetor dos Monumentos Históricos, cuja função era, percorrer o território francês,

\footnotetext{
${ }^{11}$ Ibid, p.21.

${ }^{12}$ Ibid, p.21.
} 
catalogando e inventariando os bens que julgasse de singular valor histórico, utilizando-se, todavia unicamente dos critérios de conveniência e oportunidade. Foram criados ainda diversos órgãos estatais incumbidos de proteger o patrimônio cultural.

Muito embora o Estado Francês tenha adotado políticas protecionista, os órgãos criados eram desprovidos de poder coercitivo, razão pela qual as medidas por eles adotadas eram ineficientes e infrutíferas contra a depredação do patrimônio histórico.

Em 1887, estabelece-se na França o denominado classement, instituto análogo ao tombamento, com o objetivo de tornar a atuação estatal mais enérgica.

Por derradeiro, visando tornar a classement mais eficaz, foi promulgada em 1913 a Lei sobre Monumentos Históricos (Loidu 31 décembre 1913 surles monuments historiques), vigente no território francês até os dias atuais, a qual ampliou as formas de proteção e criou novos institutos.

A nova lei ampliou as formas de proteção, criando dois novos instrumentos: instance de classement e inscription à l'inventaire supplémentaire. Além disso, o já conhecido classement passou a ser aplicável à propriedade privada, com previsão de impulso do procedimento pelo Estado mesmo diante da discordância do proprietário do bem..$^{14}$

Portanto, vê-se que a proteção do patrimônio cultural e artístico passou por diversos momentos históricos, desde a irresponsabilidade com os bens da cultura europeia, até a criação de mecanismos jurisdicionais de classificação e intervenção na propriedade particular como meio de salvaguardar tais bens, quais sejam, a classificação e o tombamento.

\section{O TOMBAMENTO E AS CONSTITUIÇÕES BRASILEIRAS}

Seguindo o legado protecionista principiado na Europa, o Brasil introduziu em seu ordenamento jurídico, a partir do século XX, "as primeiras iniciativas voltadas à proteção de bens materiais portadores de referências culturais". ${ }^{15}$

No entanto, infere-se que a primeira manifestação governamental favorável à prevenção da história brasileira data-se de 1742, ocasião em que Dom André de Melo Castro, então $5^{\circ}$ vice-rei e $4^{\circ}$ conde das Galveias, revelou-se partidário da conservação do Palácio de Friburgo, situado na Capitania Hereditária de Pernambuco, ao argumento de que o imóvel representava um monumento para a nação brasileira e simbolizava o sucesso do Governo Português ante as invasões Holandesas.

\footnotetext{
${ }^{13}$ Ibid, p.25.

${ }^{14}$ Ibid, p.29.

${ }^{15}$ Ibid, p.27.
} 
Cabe destacar, todavia, que apesar da adoção de políticas de proteção, viu-se pouca expressividade concreta da tutela, visto que acabaram por se tornar ineficazes, já que adotadas de forma isolada pela Coroa Portuguesa no Brasil.

Do mesmo modo, é certo que a Constituição de 1824 foi silente quanto à proteção jurídica dos bens culturais e históricos.

Continuamente, após a Proclamação da Independência em 1888, as Constituições passaram a adotar concepção absoluta de propriedade, o que tornou inviável à interferência do Estado em sua esfera jurídica, excepcionando-se apenas a desapropriação nos casos de necessidade ou utilidade pública, precedida de previsão legislativa, além de contar com indenização ao proprietário do imóvel, consoante disposto no artigo 72, capute $\mathbb{S}$ 17, da Constituição de 1891, in verbis:

rt.72 - A Constituição assegura a brasileiros e a estrangeiros residentes no paiz a inviolabilidade dos direitos concernentes á liberdade, á segurança individual e á propriedade, nos termos seguintes:

$\$ 17$. O direito de propriedade mantém-se em toda a sua plenitude, salvo a desapropriação por necessidade, ou utilidade pública, mediante indemnização prévia. ${ }^{16}$

No entanto, a completa desproteção legal dos patrimônios históricos nacionais cessou com a entrada em vigor da Constituição dos Estados Unidos do Brasil, promulgada em 1934, que incumbiu de forma concorrente à União e aos Estados a proteção de monumentos de valor histórico e artístico, devendo ser criados mecanismos para impedir a evasão de obras de arte.

Art. 10 - Compete concorrentemente à União e aos Estados:

III - proteger as belezas naturais e os monumentos de valor histórico ou artístico, podendo impedir a evasão de obras de arte;

Art. 148 - Cabe à União, aos Estados e aos Municípios favorecer e animar o desenvolvimento das ciências, das artes, das letras e da cultura em geral, proteger os objetos de interesse histórico e o patrimônio artístico do País, bem como prestar assistência ao trabalhador intelectual. ${ }^{17}$

Após a aprovação do regulamento do Museu Histórico Nacional, em 1934, foram introduzidas restrições ao direito de propriedade no ordenamento jurídico pátrio, dentre as quais destacam-se a imprescindibilidade de prévio consentimento da Administração Pública para a realização de reformas, modificações em imóveis catalogados como monumentos nacionais, além de restrições quanto à exportação de objetos de cunho histórico ou cultural, sejam estes públicos ou privados.

Nesse quadro, em 1936, Mario de Andrade, então Diretor do Departamento de Cultura da Cidade de São Paulo, estruturou o projeto de lei destinado a definir o patrimônio artístico nacional, bem como a criou o

16 BRASIL. Constituição da República dos Estados Unidos do Brasil, 1891, art. 72, \ 17. Disponível em: <http://www.planalto.gov.br/ccivil_03/constituicao/constituicao91.htm>. Acesso em: 05/03/14.

${ }^{17}$ BRASIL. Constituição da República dos Estados Unidos do Brasil, 1934, art. 10, inciso III, art. 148. Disponível em: <http://www.planalto.gov.br/ccivil_03/constituicao/constituicao34.htm>. Acesso em: 06/03/14. 
instituto do tombamento, destinado a proteger efetivamente o patrimônio histórico, conforme lhe fora solicitado pelo Ministro da Educação e Cultura.

O citado projeto culminou com a criação do Serviço do Patrimônio Histórico e Artístico Nacional/SPHAN, conforme consta no artigo 46, da Lei n $378 / 37$.

Atualmente o SPHAN é cognominado de Instituto do Patrimônio Histórico e Artístico Nacional/IPHAN.

Noutra senda, na vigência da Constituição de 1937 a proteção ao patrimônio histórico foi mais rígida, motivo pelo qual qualquer ato contra o patrimônio nacional era sancionado de forma análoga aos crimes previstos na legislação penal, conforme consta do o artigo 134 da Constituinte;

Os monumentos históricos, artísticos e naturais, assim como as paisagens ou os locais particularmente dotados pela natureza, gozam da proteção e dos cuidados especiais da Nação, dos Estados e dos Municípios. Os atentados contra eles cometidos serão equiparados aos cometidos contra o patrimônio nacional. ${ }^{18}$

Ainda na era Vargas, foi editado o Decreto-Lei 25 de 1937, diploma legal de maior importância para o ordenamento jurídico no que toca a proteção do patrimônio histórico e cultural. Cabe destacar que o citado decreto se encontra vigente até os dias atuais.

Por derradeiro, adotando a mesma política protecionista das constituições antepassadas, a Magna Carta de 1988 aperfeiçoou os institutos anteriormente citados, o que tornou ainda mais rigorosa a intervenção Estatal na propriedade privada.

Além disso, ao artigo 216, caput e $\$ 1^{\circ}$, da CRFB/88 delimitou os bens que constituem patrimônio cultural brasileiro. Vejamos o texto constitucional:

Art. 216. Constituem patrimônio cultural brasileiro os bens de natureza material e imaterial, tomados individualmente ou em conjunto, portadores de referência à identidade, à ação, à memória dos diferentes grupos formadores da sociedade brasileira, nos quais se incluem:

I - as formas de expressão;

II - os modos de criar, fazer e viver;

III - as criações científicas, artísticas e tecnológicas;

IV - as obras, objetos, documentos, edificações e demais espaços destinados às manifestações artístico-culturais;

$\mathrm{V}$ - os conjuntos urbanos e sítios de valor histórico, paisagístico, artístico, arqueológico, paleontológico, ecológico e científico.

\$ $1^{\circ}$ - O Poder Público, com a colaboração da comunidade, promoverá e protegerá o patrimônio cultural brasileiro, por meio de inventários, registros, vigilância, tombamento e desapropriação, e de outras formas de acautelamento e preservação. ${ }^{19}$

18 BRASIL. Constituição da República dos Estados Unidos do Brasil, 1937, art. 134 . Disponível em: <http://www.planalto.gov.br/ccivil_03/constituicao/constituicao37.htm>. Acesso em: 08/03/14.

19 BRASIL. Constituição da República Federativa do Brasil, 1988, art. 216, caput e $₫ 1$ o. Disponível em: <http://www.planalto.gov.br/ccivil_03/constituicao/constituicao.htm>.Acesso em: 10/03/14. 
Por derradeiro, cabe salientar que o rol constante na Magna Carta é meramente exemplificativo, visto que utilizada expressões genéricas para enumerá-los.

\section{PRINCÍPIOS REITORES DA INTERVENÇÃO ESTATAL NA PROPRIEDADE PRIVADA}

Inicialmente, impende destacar que os princípios são normas fundamentais de caráter geral e de orientação dúplice, ou seja, devem ser utilizados pelo legislador no momento da elaboração da norma positiva, assim como pelo aplicador da norma, ante a omissão legal, sendo, portanto, intrínseco ao conceito de direito.

Direito é o conjunto de princípios, regras e institutos voltados a organizar relações, situações ou instituições, criando vantagens, obrigações e deveres no contexto social. ${ }^{20}$

Princípios de uma ciência são as proposições básicas, fundamentais, típicas que condicionam todas as estruturações subsequentes. Princípios, neste sentido, são os alicerces da ciência.. ${ }^{21}$

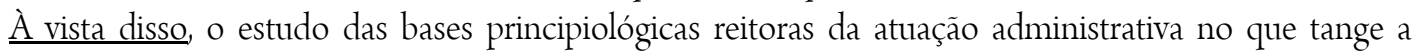
intervenção do poder público na propriedade privada é de substancial relevância.

Preambularmente infere-se que o princípio da supremacia do interesse público é considerado como um dos alicerces do direito administrativo brasileiro, paritariamente com o princípio da indisponibilidade do interesse público.

Dessa maneira, depreende-se que as atividades desempenhadas pela Administração Pública têm como finalidade precípua o benefício da coletividade, podendo, em decorrência disso, restringir e/ou limitar os interesses individuais para salvaguardar o interesse público, fazendo-se presente na atuação do Estado no momento da elaboração da norma, bem como no momento da aplicação em concreto pela Administração Pública, repelir, relativamente, o individualismo.

Exemplo clássico da incidência deste princípio são as intervenções estatais na propriedade privada, uma vez que o interesse individual resta prejudicado frente ao relevante interesse coletivo na preservação de determinado patrimônio histórico ou cultural, como ocorre no tombamento, outro exemplo tradicional é o exercício regular do poder de polícia.

Noutra senda, imperioso dissertar sobre o princípio da legalidade, que também possui especial relevo no que toca a intervenção administrativa na propriedade particular.

A legalidade deve ser vislumbrada de forma bipartida, observando-se diretrizes distintas para a sociedade e para a administração pública. Para aquela, vige a absoluta liberdade de atuação, isto é, não se condiciona as condutas do particular a prévia autorização legal. Caso inexista vedação legal, será lícita a atuação (art.5\% II, da Constituição Federal).

\footnotetext{
${ }^{20}$ DELGADO, Mauricio Godinho. Princípios de Direito Individual e Coletivo do Trabalho. Rev. TST. 2009, p.1. Disponível em: <http://www.tst.jus.br/documents/1295387/1312882/1.+Os+princ\%C3\%ADpios+na+estrutura+do+Direito>. Acesso em: 10/04/14.

${ }^{21}$ CRETELLA JÚNIOR, José, apud PIETRO Maria Sylvia Zanella Di. Direito Administrativo. São Paulo: Atlas, 2011, p.63. vol.10, no. 01, Rio de Janeiro, 2017.pp.95-126 
Ao contrário sensu, a atuação administrativa está absolutamente vinculada à previsão legal expressa. Tal postulado visa impedir que os agentes públicos atuem indiscriminadamente e gerem prejuízos irreparáveis aos interesses públicos.

Portanto, a previsão constitucional do princípio da legalidade tem por escopo precípuo a manutenção da lisura e a probidade na atuação estatal e no trato a dos interesses públicos pela administração, evitando, pois, a existência de atos administrativos viciados e maculados pela má-fé, sendo de fundamental importância no combate aos prejuízos causados ao interesse público e a coletividade pela atuação desregrada e desonesta.

Por derradeiro, realça-se o princípio da eficiência na atuação do poder público, fruto da reforma administrativa na Constituição Federal, implementada por meio da Emenda Constitucional 19/98.

O princípio da eficiência foi introduzido expressamente na ordem constitucional com a chamada reforma administrativa (promovida pela Emenda Constitucional no 19/98). O princípio, assim, passa a figurar expressamente entre aquelas já constantes do caput do art.37.22

O postulado teve sua origem no direito privado, muito embora fosse considerado pela doutrina administrativista como implícito na Constituição, tendo em vista a sua vital importância.

De mais a mais, percebe-se que o princípio em testilha tem por finalidade a busca pela economicidade na administração, em outras palavras, visa manter a qualidade dos serviços prestados com o menor dispêndio para a administração e consequentemente para as finanças públicas.

Sob essa ótica, busca-se atenuar a burocratização do serviço público, tornando-o mais célere. Objetiva também a maior presteza e rendimento funcional. Exemplo da atuação eficiente é a criação de agências reguladoras, que exercem fiscalização e controle sobre os serviços públicos delegados a particulares, como a Agência Nacional de Energia Elétrica (ANEEL), primeira agência reguladora criada no Brasil.

\section{DA PROTEÇÃO DO PATRIMÔNIO HISTÓRICO, CULTURAL E ARTÍSTICO}

Como já ressaltado, a proteção dos bens de interesses culturais, artísticos e históricos passou por inúmeras fases, tais como a absoluta desproteção jurídica e inexistência de dispositivos legislativos e jurisdicionais hábeis a salvaguardá-los, bem como a proteção constitucional de tais bens de interesse nacional ou regional, demonstrando a recente preocupação do poder constituinte com a manutenção da história e cultura brasileira.

Embora a proteção jurídica dos bens históricos tenha se servido de diversos dispositivos legais, o Decreto-Lei Federal n²5, de 30 de novembro de 1937 pode ser elencado como a norma basilar do tombamento no Brasil, visto que criou mecanismos jurisdicionais aptos a dar a efetiva proteção ao patrimônio histórico e artístico nacional.

Nessa vereda, abstrai-se que o citado Decreto-Lei foi idealizado por Rodrigo Melo Franco de Andrade, 
membro do Ministério da Educação e Saúde durante a Era Vargas e diretor da Instituição Federal de Preservação do Patrimônio Histórico e Artístico Nacional, atualmente denominado IPHAN.

Igualmente, cabe salientar que o Decreto-Lei é considerado pela doutrina administrativista como a primeira norma a tratar substancial e objetivamente dos bens históricos, culturais e artísticos de interesse nacional e regional.

Conforme descrito no artigo $1^{\circ}$ do Decreto-Lei 25/37, o patrimônio histórico e artístico brasileiro é composto por bens móveis e imóveis, existente no país e cuja conservação seja de interesse público e estejam relacionados à fatos memoráveis da história brasileira, além de possuíres valor arqueológico, artístico ou bibliográfico.

Oportuno frisar também que, o principal meio de proteção trazido a lume pelo referido Decreto-Lei foi o tombamento, uma vez que se caracteriza como verdadeira limitação ao direito de propriedade, como forma de salvaguardar os bens descritos no artigo $1^{\circ}$.

Apesar do Decreto-Lei seja septuagenário e, por tal razão, padeça de diversas críticas doutrinárias quanto a sua eficácia na contemporaneidade, continua sendo a legislação que estabelece as regras gerais do tombamento e que proporciona mecanismos hábeis a salvaguardar os bens de interesse público.

Nesse sentido, preceitua do conceituado Procurador de Justiça do Estado do Rio de Janeiro e professor Carvalho Filho (2011):

O diploma infraconstitucional regulador do tombamento é o Decreto-lei $n^{\circ} 25$, de 30/11/1937, que, sem embargo de desatualizado em alguns pontos, contém ainda as regras básicas e a fisionomia jurídica do instituto do tombamento, inclusive quanto ao registro de bens tombados. Note-se, porém, que esse Decreto-lei apenas traça as regras gerais aplicáveis ao fato jurídico-administrativo do tombamento. Mas este se consumará como adiante veremos, através de atos administrativos específicos destinados a propriedades determinadas. ${ }^{23}$

Importante realçar que o Decreto-Lei n ${ }^{\circ}$ 25/1937 estabelece os ditames legais por meio dos quais o tombamento deve ser realizado, como por exemplo, o procedimento de inscrição do bem tombado no livro do tombo, previsto em seu artigo $4^{\circ}$.

Do mesmo modo, é evidente que o tombamento é uma restrição parcial ao direito de propriedade, isto é, não impede que o particular exerça os direitos intrínsecos ao seu domínio. Por tais razões, o instituto em tela é comumente associado à inexistência de indenização ao proprietário, motivo pelo qual sua a incidência normalmente é repudiada pelos particulares.

Porém, parcela da doutrina critica a inexistência de previsão legal sobre a compensação pecuniária nos casos de intervenção não supressiva na propriedade privada. $\mathrm{O}$ argumento utilizado por essa corrente de administrativistas era o disposto no artigo 1.228, do Código Civil, que prevê indenização aos proprietários que

${ }^{22}$ TAVARES, André Ramos. Curso de Direito Constitucional. 8 ed. São Paulo: Saraiva, 2010, p.1327. 
sofrerem esbulho de terceiros.

Nota-se, outrossim, que o princípio da isonomia também é utilizado pela doutrina como fundamento para defender o direito de indenização, uma vez que apenas um indivíduo suportaria o prejuízo em benefício da coletividade, senão vejamos:

De qualquer sorte, uma vez que a ação administrativa se destina a beneficiar a coletividade, repugna ao princípio da isonomia que os danos jurídicos dela procedentes sejam individualmente suportados. Daí a exigência de que tais prejuízos sejam partilhados entre todos os beneficiários, o que se traduz, com fundamento no referido princípio, no dever estatal de indenizar. ${ }^{24}$

No entanto, a compensação pecuniária é devida somente de forma excepcional, quando restar efetivamente demonstrado o prejuízo financeiro ao proprietário em decorrência da intervenção estatal.

Assim, haverá dever de indenizar apenas em hipóteses específicas, quais sejam, ocorrência de dano patrimonial, devidamente aferido, após a instituição do tombamento, bem como quando ocorrer o "esvaziamento econômico do bem"25 e, por fim, caso ocorra à desapropriação indireta, isto é, a obrigações impostas ao proprietário por meio do tombamento tornam inviável a utilização do bem, caracterizando ônus insuportável, culminando na reparação pecuniária do dano causado.

Desta forma, conclui-se que, em regra, a incidência de qualquer gravame atinente ao tombamento não é presumidamente indenizável, carecendo de efetiva demonstração do prejuízo econômico e não meramente jurídico.

Relativamente às políticas públicas e econômicas, em especial aos incentivos fiscais como forma de fomentar a preservação do patrimônio histórico, infere-se que estes se materializam por meio da dedução do imposto de renda, em índices de até 80\% das despesas efetuadas para restaurar, preservar e conservar os bens tombados pelo IPHAN, no caso de pessoas físicas.

Imperioso destacar que os parâmetros gerais de concessão de estímulos fiscais e tributários estão previstos na Lei n $8.313 / 91$ (Lei Rouanet), o que não impede a edição de legislações específicas de incentivo à cultura e a preservação histórica pelos Estados da Federação ou pelas Municipalidades.

Do mesmo modo, oportuno trazer à baila as elocuções da Lei n 18.030, de 12 de janeiro de 2009, conhecida vulgarmente por “Lei Robin Hood”, promulgada no Estado de Minas Gerais.

A referida legislação dispõe sobre a distribuição da parcela da receita do produto da arrecadação do ICMS pertencente aos Municípios. Estabelece o artigo $1^{\circ}$, inciso VII, que a parcela da receita do produto da arrecadação do ICMS (artigo 150, $\$ 11^{\circ}$, da Constituição Federal), terá como critério de distribuição, dentre outros, o patrimônio cultural municipal, a ser fornecido pelo IEPHA.

${ }^{23}$ CARVALHO FILHO, José dos Santos. Manual de Direito Administrativo. Rio de Janeiro: Lumen Juris, 2011, p.735.

${ }^{24}$ ZANDONADE, Adriana. O Tombamento à Luz da Constituição Federal de 1988. São Paulo: Malheiros, 2012, p.162. vol.10, no. 01, Rio de Janeiro, 2017.pp.95-126 
Em igual sentido, o Município de São Paulo estabeleceu, por meio da Lei Municipal nº 10.923/90, a isenção parcial do Imposto Predial e Territorial Urbano (IPTU) e do Imposto sobre Serviços de Qualquer Natureza (ISS) para aplicação em obras de conservação e restauração de bens tombados em índices de desconto de 30\%, além de atribuir à Câmara Municipal a competência para fixar anualmente o uso do ISS e do IPTU em ações de incentivo a cultura.

Esse exemplo também é seguido pelos municípios de Curitiba/PR, Recife/PE, Vitória/ES, Salvador/BA, dentre outros.

Quanto ao tema, prelecionada a secretária de cultura cearense Leitão (2005):

No Estado moderno brasileiro, por exemplo, proliferam leis de patrocínio cultural. Travestidas nos mais diversos figurinos, sejam elas de âmbito federal, estadual ou municipal, os mecanismos legislativos têm como estrutura básica à renúncia fiscal, para atrair parceiros da empresa privada para que subsidiem a produção artística. Ou seja, a empresa aplica algum dinheiro em algum projeto artístico e em troca abate a quantia ou parte dela do seu saldo a pagar de Imposto de Renda, ICMS, IPTU ou ISS. ${ }^{26}$

Desta forma, é certo que o estabelecimento de benefícios fiscais e tributários como formas de incentivo a proteção evidencia uma preocupação com o patrimônio cada vez mais presente na sociedade e em nossa legislação.

Nesse contexto, destacam-se os ensinamentos do Promotor de Justiça Marcos Paulo de Souza Miranda, Coordenador da Promotoria de Justiça de Defesa do Patrimônio Histórico, Cultural e Turístico do Estado de Minas Gerais, quanto à instituição de incentivos fiscais e tributários aos proprietários de bens tombados, senão vejamos:

Nesse sentido, o Estatuto das Cidades (Lei 10.257/2001) incorporou expressamente a concessão de incentivos e benefícios fiscais e financeiros como instrumento orientador das políticas de gestão urbana (em que o patrimônio cultural é um dos elementos mais importantes) e estabeleceu no art. 47 que "Os tributos sobre imóveis urbanos, assim como as tarifas relativas a serviços públicos urbanos, serão diferenciados em função do interesse social". ${ }^{27}$

Importante averbar que o tombamento é erroneamente associado as formas de intervenção absoluta na propriedade, sendo comumente difundida a ideia de que o proprietário fica privado alienar o bem ou de realizar qualquer modificação estrutural, sem que seja conferida nenhuma contrapartida pecuniária.

Todavia, conforme acima esposado, é possível a concessão de diversas benesses aos proprietários, como incentivos fiscais e tributários ou, em casos específicos, até mesmo indenizações pecuniárias.

\footnotetext{
${ }^{25}$ OLMO, Manolo Del. Tombamento: aspectos jurídicos. Jus Navigandi, Teresina, ano 5, n. 48, 1dez.2000. Disponível em: <http://jus.com.br/artigos/486/tombamento>. Acesso em: 26/04/14.

${ }^{26}$ LEITÃO, Cláudia Sousa apud SILVA, Marcus Flávio Alexandre Da. A política de incentivo à cultura no Ceará a partir da Lei Jereissati. 2005. 158 p. Dissertação (Mestrado Acadêmico em Políticas Públicas e Sociedade) - Universidade Estadual do Ceará, Centro de Estudos Sociais Aplicados. Fortaleza, Ceará, 2005.

${ }^{27}$ MIRANDA, Marcos Paulo de Souza. Benefícios para proprietários de bens tombados. Jus Navigandi, Teresina, ano 15, n. 2667, 20 out. 2010. Disponível em: <http://jus.com.br/artigos/17636/beneficios-para-proprietarios-de-bens-tombados>. Acesso em: $05 / 05 / 14$
} 


\section{DAS POLÍticAS PÚBLICAS COMO MECANISMOS DE PROTEÇÃO DO PATRIMÔNIO HISTÓRICO}

Doravante, no citado artigo 216 da Magna Carta de 1988, restou determinado que o Poder Público, em colaboração da comunidade, promoverá e protegerá o patrimônio cultural brasileiro, por meio de inventários, registros, vigilância, tombamento e desapropriação, e de outras formas de acautelamento e preservação.

Seguindo os mandamentos constitucionais, diversos Estados da Federação também incluíram em sua Constituição do dever de proteção ao patrimônio histórico e cultural, cita-se como exemplo a Constituição do Estado de Minas Gerias, que em seu artigo 209, caput, prevê, inclusive, meios de efetivação da tutela protetiva.

Noutra banda, é dever da Administração Pública, bem como da sociedade preservar e proteger os bens que integram o patrimônio cultural, de modo a observar e respeitar a solidariedade intergeracional.

Tais previsões têm como escopo principal proporcionar que as futuras gerações possam usufruir de recursos culturais e que de bens que tenham marcado nossa história.

Partindo-se destes pressupostos, cabe asseverar que, não apenas os entes da esfera federal e estadual preconizaram em suas legislações a devida proteção a esses bens.

Isto porque, a municipalidade deve atentar também para a criação de políticas urbanas com o fito de desenvolver as funções sociais da propriedade, bem como estabelecer diretrizes de preservação e recuperação do patrimônio cultural, histórico, artístico, paisagístico e arqueológico, tal como disposto no artigo $2^{\circ}$, inciso XII, da Lei n ${ }^{\circ}$ 10.257/01 (Estatuto das Cidades).

Relativamente ao Estatuto das Cidades, é importante lembrar que foi estabelecido importante mecanismo de tutela protetiva, qual seja, direito de preempção, que significa a preferência do Poder Municipal na aquisição de um imóvel que esteja na iminência de ser vendido pelo particular, tal como insculpido no artigo 26, inciso VIII, do referido Estatuto.

Nesse contexto, Ackel Filho (2013) preceitua que:

O dever de tutela do Município associado às obrigações federais e estaduais no mesmo sentido não se restringe a uma proteção genérica. Exige-se o cuidado específico quanto à preservação de tais bens em seu conteúdo original. A devastação e o vandalismo que, infelizmente, proliferam em nosso País, sem qualquer respeito a esses valores culturais, justificam a preocupação do legislador constituinte, tornando obrigação também do Município a adoção de medidas eficazes no sentido de garantir a incolumidade desses bens, exercendo com rigor o seu poder de polícia no que tange à matéria. ${ }^{28}$

Em epítome, observa-se que de forma hierárquica, as respectivas legislações estabeleceram que os entes da administração pública direta possuem o dever de atuarem de forma colaborativa e integrativa entre em si e com a sociedade na preservação e conservação de bens de interesse histórico, cultural ou paisagístico, não sendo,

\footnotetext{
${ }^{28}$ ACKEL FILHO, Diomar apud REZENDE, Renato Teixeira; LOPO, Fabrício Costa. Ministério Público do Estado de Minas Gerais. Ação Civil Pública - Curadoria de Defesa do Patrimônio Cultural, Frutal, 2013, p.37.
} 
portanto, obrigação única e exclusiva da União, Estados ou Municípios, mas sim do Poder Público lato sensu, visando, pois, garantir maior eficácia na efetivação deste dever estatal e social.

Nesse contexto, oportuno conceituar políticas públicas, é o conjunto de programas e ações elaboradas pelo Estado, de forma direta ou indireta, com a participação conjunta dos entes públicos e/ou privados, com o objetivo de garantir os direitos inerentes à cidadania, seja de forma difusa ou individualizada, que são de responsabilidade estatal.

Quanto à elaboração das políticas públicas, observa-se que a iniciativa pode partir do poder executivo e/ou legislativo, além das propostas elaboradas pela própria sociedade, que leva ao conhecimento da Administração Pública suas necessidades fundamentais, sobretudo aqueles relativas à saúde, educação, lazer e cultura

Quanto às políticas públicas direcionadas a proteção e conservação do patrimônio histórico, destaca-se o Conselho Nacional de Política Cultural (CNPC), órgão integrante da estrutura básica do Ministério da Cultura, que tem a finalidade precípua a elaboração de:

Propor a formulação de políticas públicas, com vistas a promover a articulação e o debate dos diferentes níveis de governo e a sociedade civil organizada, para o desenvolvimento e o fomento das atividades culturais no território nacional..$^{29}$

Por seu turno, no que tange a competência do Plenário do CNPC, tem-se que este deve acompanhar e fiscalizar a execução do Plano Nacional de Cultura estabelecer as diretrizes gerais para aplicação dos recursos do Fundo Nacional de Cultura, dentre outras.

Deste modo, visando dar plena efetividade aos preceitos constitucionais do artigo 216, cumpre ao CNPC criar diretrizes gerais de proteção à cultura e a história.

Para tanto, o Decreto n 5.520/05 estabeleceu, em seu artigo 1', a instituição do Sistema Federal de Cultura (SFC), que tem a finalidade de contribuir para a implementação de políticas culturais democráticas e permanentes, pactuadas, articular ações com vistas a estabelecer e efetivar, no âmbito federal, o Plano Nacional de Cultura.

Outrossim, o artigo $2^{\circ}$ do citado decreto, estabeleceu que o IPHAN integrará o SFC, a fim de integralizar o sistema de proteção jurídica dos bens de interesse público e propiciar maior resguarda aos bens a serem protegidos e evitar possíveis contradições e obscuridades na edição de diretrizes protecionistas.

Concomitantemente, frisa-se que tais políticas não são obrigações inerentes apenas ao Ministério da Cultura e seus órgãos contíguos, mas também dos entes federativos estaduais.

Oportuno lembrar que existem órgãos análogos ao CNDC e ao IPHAN no âmbito estadual, cita-se como exemplo, o Instituto Estadual do Patrimônio Histórico e Artístico de Minas Gerais (IEPHA), bem como a

\footnotetext{
${ }^{29}$ BRASIL. Ministério da Cultura. O CNPC (Conselho Nacional de Política Cultural). Brasília, 2013. Disponível em: <http://www.cultura.gov.br/cnpc/o-cnpc>. Acesso em: 30/05/14.
} 
Coordenadoria de Patrimônio Histórico e Cultural (CPHC), que integra a estrutura da Secretaria de Cultura de Fortaleza (Secultfor), os quais possuem poderes para a criação de diretrizes de proteção os bens históricos e artísticos de suas regiões, atuando em cumplicidade com a sociedade e o IPHAN, além do CNDC.

Em síntese, perfaz-se que a entabulação de políticas públicas hábeis a conscientizar a sociedade quanto à importância da preservação e da manutenção da história é dever inerente a gestão da administração pública, visto que a cultura e a história são a maneira encontrada pelo homem de interagir e se relacionar direta ou indiretamente com a natureza e com os outros homens, de modo intergeracional, seja pelas manifestações arquitetônicas ou pelo estilo de vida adotado em determinada época, sendo, portanto, elemento de suma importância para a civilização.

\section{ATUAÇÃO DO MINISTÉRIO PÚBLICO}

Primordialmente, importante trazer a lume o conceito de direitos difusos.

São aqueles direitos que não podem ser atribuídos a um grupo de pessoas, vez que dizem respeito a toda a sociedade indistintamente, ou seja, inexiste possibilidade de identificação dos titulares subjetivos do direito salvaguardado. Desta forma, com a ocorrência de um evento danoso a um direito difuso este afetará, direta ou indiretamente, a qualidade de vida de toda a população.

Nesse sentido, o Código de Defesa do Consumidor (CDC), trata da conceituação dos interesses ou direitos difusos em seu artigo 81, inciso I, dissertando que direitos difusos são aqueles que possuem natureza indivisível, de que sejam titulares pessoas indeterminadas e ligadas por uma circunstância fática.

A indeterminação da titularidade dos direitos difusos a ser tutelado é o motivo pelo qual o legislador constituinte incumbiu ao Ministério Público o dever de salvaguardá-los.

Nesse rumo, visando dar plena efetividade as atribuições constitucionais do Ministério Público foram disponibilizados aos Parquet diversos mecanismos jurisdicionais passíveis de proporcionar a tutela cogente, quais sejam, a promoção do inquérito civil e da ação civil pública, com o cunho de proteger, dentre outros, o patrimônio público e social, conforme consta do artigo 129, inciso III, da Constituição Federal.

Nesse sentido, Mendes disserta quanto o cabimento da ação civil pública, entre os quais, destaca os bens e direitos de valor artístico, estético, histórico, turístico, paisagístico, que são objeto do presente estudo, aduzindo, inclusive, quanto à previsão constitucional:

Outro relevante instrumento de defesa do interesse geral é a ação civil pública prevista no art. 129, III, da Constituição e destinada à defesa dos chamados interesses difusos e coletivos relativos ao patrimônio público e social, ao meio ambiente, ao consumidor, a bens e direitos de valor artístico, estético, histórico, turístico, paisagístico, da ordem econômica e da economia popular, dentre outros. ${ }^{30}$

\footnotetext{
${ }^{30}$ MENDES, Gilmar Ferreira; BRANCO, Paulo Gustavo Gonet. Curso de Direito Constitucional. São Paulo: Saraiva, 2012 , p.544. vol.10, nº. 01, Rio de Janeiro, 2017.pp.95-126 
A ação civil tem-se constituído em significativo instituto de defesa de interesses difusos e coletivos e, embora não voltada, por definição, para a defesa de posições individuais ou singulares, tem-se constituído também em importante instrumento de defesa dos direitos em geral, especialmente os direitos do consumidor.

Conquanto, há que se advertir para o fato de que não serão cabíveis em sede de ação civil pública questões relativas ao tombamento ou a desapropriação, já que se busca a tutela protecionista ao patrimônio histórico e cultural.

Nessa vereda, acentua-se que a proteção dos bens históricos não se limita ao processo de tombamento, sendo possível o manejo de ações civis públicas com o mesmo mote, conforme consta na Lei nº 7.347/85, vejamos os dizeres de Mazilli (1991) sobre o tema:

O legislador não limitou a proteção ao bem tombado, é possível proteger por meio da Lei da Ação Civil Pública monumentos arqueológicos, pré-históricos, florestas, áreas públicas etc., anda que não tombados. ${ }^{31}$

Giro outro, imperioso destacar que não apenas o Ministério Público possui legitimidade para ajuizar ações em defesa dos direitos difusos.

Isto porque, o artigo $5^{\circ}$, da Lei de Ação Civil Pública atribui à Defensoria Pública, aos Entes Federados, entes da Administração Pública Indireta (autarquias, empresas públicas, fundações e sociedades de economia mista) e as associações plena legitimidade para encabeçaram a Ação Civil Pública.

No que tange a legitimidade para a propositura da ação civil pública esclarece Mendes (2012):

Têm legitimidade para a propositura dessa ação o Ministério Público, as pessoas jurídicas de direito público, as empresas públicas e sociedades de economia mista, as associações constituídas há pelo menos um ano, nos termos da lei civil, que incluam entre as suas finalidades institucionais a proteção de interesses difusos ou coletivos. (cf. Lei n. 7.347/85, art. $\left.5^{\circ}\right) .{ }^{32}$

Entretanto, é certo que o Ministério Público continua sendo o órgão legitimado que mais propõe ações civis pública, conforme é verificado no Relatório-Diagnóstico 2002-2010, publicado no sítio do Ministério Público do Estado de São Paulo. Segundo o citado relatório entre os anos de 2009 e 2010 foram propostas 5.712 ações civis públicas no Estado de São Paulo pelo Ministério Público Estadual, consoante dissertado pelo professor Lenza (2007):

Para se ter um dado estatístico, atualizado em relação às ações civil públicas propostas no Estado de São Paulo, de acordo com o relatório de atividades do ministério público em primeira instancia, publicado a mando do Sr. Corregedor Geral no DOESP de 09.11.2001, existia, em andamento no Estado de São Paulo, 7.749 ações civis públicas. Desse total, 7.409 tinham sido ajuizadas pelo Ministério Público paulista, ao passo que 570 pelos outros colegitimados. ${ }^{33}$

A partir destes dados estatísticos é possível notar que, embora Constituição Federal de 1988 e a Lei nº

\footnotetext{
${ }^{31}$ MAZZILLI, Hugo Nigro. Manual do promotor de Justiça. São Paulo: Saraiva, 1991, p.491.

${ }^{32}$ MENDES, Gilmar Ferreira; BRANCO, Paulo Gustavo Gonet. Curso de Direito Constitucional. São Paulo: Saraiva, 2012, p.544.

${ }^{33}$ LENZA, Pedro apud MANCUSO, Rodolfo de Camargo. Ação Civil Pública: Em defesa do meio ambiente, do patrimônio cultural e dos consumidores: Lei 7.347/85 e legislação complementar. São Paulo: Revista dos Tribunais, 2007, p.1 12. vol.10, nº. 01, Rio de Janeiro, 2017.pp. 95-126 
7.347/85 tenham legitimados diversos órgãos para a tutela dos direitos difusos e coletivos, estes não atuam com a devida assiduidade, visto que propõe ínfimo número de ações civis públicas, com exceção do Ministério Público e da Defensoria Pública.

\section{INSTITUTO DO PATRIMÔNIO HISTÓRICO E ARTÍSTICO NACIONAL (IPHAN)}

O Instituto do Patrimônio Histórico e Artístico Nacional (IPHAN) possui natureza jurídica de autarquia federal, tendo sido criada em 1937, por Rodrigo Melo Franco de Andrade durante a Era Vargas.

A criação do IPHAN se deu por meio da Lei n $378 / 37$, que posteriormente culminou com a edição do Decreto-lei n 25/37, o qual pode ser considerado o grande marco histórico para o patrimônio histórico e artístico nacional.

Nesse quadro, é certo afirmar que a criação do IPHAN é considerada como a medida pública de maior notabilidade da Administração Pública Federal na defesa do patrimônio cultural e artístico, visto que erigiu em concomitância com o regime ditatorial e com a participação dos intelectuais modernistas advindos da semana de arte moderna de 1922.

Oportuno gizar, em apertada síntese, que a autarquia possui a precípua função de proteger os bens de natureza material e imaterial, tangível e intangível, considerados de forma individual ou em conjunto, isto é, compete ao IPHAN preservar, identificar, fiscalizar, revitalizar, restaurar e divulgar os bens culturais brasileiros.

Também é oportuno tecer que, conforme preconizado pelo regimento interno do IPHAN, a missão deste é promover e coordenar o processo de preservação do patrimônio cultural brasileiro visando fortalecer identidades, garantir o direito à memória e contribuir para o desenvolvimento socioeconômico do País, bem como dar provimento as digressões do já citado artigo 216 da Constituição Federal.

Á vista disso, infere-se que o centro nevrálgico das atribuições do IPHAN é a busca pela formação e conservação da identidade cultural e artística nacional, visto que refletem a representação intelectual do povo de determinada época e localidade.

Portanto, a importância do IPHAN é inegável, uma vez que é o órgão responsável pela realização do tombamento na esfera federal, bem como pela concretização da política nacional de patrimônio, além da instituição de diretrizes de proteção em sentido amplo.

Deve-se notar que o IPHAN ramifica suas atribuições por meio de superintendências regionais, tal como ocorre em Minas Gerais com o IEPHA, conseguindo assim, salvaguardar os patrimônios históricos e culturais brasileiros, mesmo que situados nos locais mais longínquos e remotos. 


\section{DA AÇÃO POPULAR COMO MECANISMO DE PROTEÇÃO}

A ação popular é um remédio constitucional previsto no artigo $5^{\circ}$, inciso LXXIII, da Constituição Federal e possibilita que qualquer cidadão seja parte legítima para anular atos lesivos ao patrimônio público ou a entidade de que o Estado participe, o que certamente inclui o patrimônio, histórico e cultural.

Desta feita, é certo que o Poder Constituinte quis trazer a lume "instrumentos de defesa de interesse geral”34, cujo cidadão possa obter controle sob os atos ilegais ou lesivos.

Art. $5^{\circ}$ Todos são iguais perante a lei, sem distinção de qualquer natureza, garantindo-se aos brasileiros e aos estrangeiros residentes no País a inviolabilidade do direito à vida, à liberdade, à igualdade, à segurança e à propriedade, nos termos seguintes:

LXXIII - qualquer cidadão é parte legítima para propor ação popular que vise a anular ato lesivo ao patrimônio público ou de entidade de que o Estado participe, à moralidade administrativa, ao meio ambiente e ao patrimônio histórico e cultural, ficando o autor, salvo comprovada má-fé, isento de custas judiciais e do ônus da sucumbência; (Grifo nosso). ${ }^{35}$

Importante destacar que a ação civil pública é um meio processual posto à disposição de qualquer cidadão, possibilitando, o controle dos atos emanados da administração pública, sendo, pois, instrumento da cidadania, tal como preconiza o Ministro Mendes em sua obra constitucionalista:

Considerando-se o caráter marcadamente público dessa ação constitucional, o autor está, em princípio, isento de custas judiciais e do ônus da sucumbência, salvo comprovada má-fé (art. 5\% LXXIII, da CF/88). A ação popular é um instrumento típico da cidadania e somente pode ser proposta pelo cidadão, aqui entendido como aquele que não apresente pendências no que concerne às obrigações cívicas, militares e eleitorais que, por lei, sejam exigíveis. ${ }^{36}$

Há que se notar também que a propositura da actio popularis depende de dois requisitos básicos, quais sejam, requisito subjetivo e requisito objetivo.

O primeiro trata da legitimidade ad causam, que é conferida pela Constituição Federal a todo cidadão brasileiro, entendido como aquele possuído de direitos políticos.

O segundo requisito refere-se à natureza do ato praticado pela Administração Pública em detrimento do interesse público e da moralidade administrativa, passível de ser impugnado.

A atuação do Ministério Público na ação popular restringe-se a intervenção tipificada no artigo 9² da Lei $n^{\circ} 4.717 / 65$, caso em que o autor principal da ação a tenha abandonado, ficando a cargo de o parquet dar-lhe seguimento, nesse sentido Mazzilli (1991):

Enquanto órgão do Ministério Público, a Lei no. 4.717/65 não lhe conferiu legitimidade originária para propor a ação popular, mas tão-somente para assumi-la, em caso de abandono pelo autor (art. $\left.9^{\circ}\right)$.

Assim, em regra, a atuação ministerial na ação popular é de órgão interveniente. ${ }^{37}$

Realça-se que, o juízo competente para o julgamento da ação será o do local onde o ato lesivo se

\footnotetext{
${ }^{34}$ MENDES, Gilmar Ferreira; BRANCO, Paulo Gustavo Gonet. Curso de Direito Constitucional. São Paulo: Saraiva, 2012, p.491.

35 BRASIL. Constituição da República dos Estados Unidos do Brasil, 1891, art. 5o, inciso LXXIII. Disponível em: <http://www.planalto.gov.br/ccivil_03/constituicao/constituicao.htm>. Acesso em: 09/06/14.

${ }^{36}$ MENDES, Gilmar Ferreira; BRAN̄CO, Paulo Gustavo Gonet. Curso de Direito Constitucional. São Paulo: Saraiva, 2012, p.544. vol.10, nº. 01, Rio de Janeiro, 2017.pp.95-126 
originou, consoante redação do art.5\% da Lei no $4.717 / 65$.

Interessante notar também o caráter impessoal despendido a ação popular, tendo em vista que o objeto precípuo dessa ação é o resguardo da coisa pública, não sendo, portanto, utilizada para a defesa do interesse particular ou do cidadão de forma individualizada.

Isto é, o que caracteriza a ação popular é sua impessoalidade, visto que a res publica pertence a coletividade indistintamente considerada.

Embora a ação popular encontre fundamento legal no artigo $5^{\circ}$ da Constituição Cidadã, a regulamentação é consagrada por meio da Lei n 4.717/65, que traz em seu bojo o rol de legitimados para a propositura da ação, o conceito de patrimônio público, objeto direto do remédio constitucional, competência, bem como o procedimento a ser adotado no transcorrer processual, tal como acentuando por Mendes; Branco (2012):

A ação popular, regulada pela Lei no. 4.717, de 29-6-1965, configura instrumento de defesa de interesse público. Não tem em vista primacialmente a defesa de posições individuais. É evidente, porém, que as decisões tomadas em sede de ação popular podem ter reflexos sobre posições subjetivas. ${ }^{38}$

No que concerne ao procedimento a ser adotado para a ação popular, o artigo $7^{\circ}$, da lei regulamentadora preceitua que a ação deverá obedecer ao procedimento ordinário, previsto no Código de Processo Civil.

Com efeito, sendo julgado procedente o pedido pleiteado no bojo da ação popular, o juízo competente deverá decretar a invalidade do ato objeto da impugnação, condenar os responsáveis pela realização deste e seus beneficiários ao adimplemento de perdas e danos, sendo possível, nesse caso, a ação regressiva em face dos funcionários causadores do dano.

Deverão ainda arcar com o pagamento das custas e despesas processuais, sejam essas judiciais ou extrajudiciais, além dos honorários advocatícios, tal como disposto nos artigos 11 e 12 da Lei nº.717/65.

Nesse diapasão, abstrai-se que o combate à imoralidade administrativa e aos atos lesivos ao patrimônio histórico, cultural e artístico é ininterruptamente a meta a ser alcançada com a propositura do remédio em testilha, tendo por escopo ressarcir os prejuízos causados por meio do ato lesivo repreendendo, bem como evitar a prática de novos atos análogos com a demonstração de enérgica punição, caracterizando, portanto, o caráter preventivo e educativo da sentença condenatória.

Por derradeiro, destaca-se que ao conferir a todos os cidadãos a legitimidade para propor a ação popular, o Poder Constituinte objetivou dar efetividade a cidadania, proporcionando a estes mecanismos jurisdicionais de controle administrativo e de combate repressivo a prática de atos imorais e lesivos ao patrimônio histórico nacional e regional.

\footnotetext{
${ }^{37}$ MAZZILLI, Hugo Nigro. Manual do promotor de Justiça. São Paulo: Saraiva, 1991, p.315.

${ }^{38}$ MENDES, Gilmar Ferreira; BRANCO, Paulo Gustavo Gonet. Curso de Direito Constitucional. São Paulo: Saraiva, 2012 , p. 544. vol.10, nº. 01, Rio de Janeiro, 2017.pp.95-126 


\section{DO PROCESSO DE TOMBAMENTO}

Quando o Estado intervém na propriedade por meio do tombamento, utilizando-o como forma de proteção ao patrimônio histórico e cultural, tem por escopo a conservação da memória nacional, visto que esta representa a "fonte sociológica de identificação dos vários fenômenos sociais, políticos e econômicos existentes na atualidade". 39

Nessa conjunção, o artigo 216, caput, da Constituição Federal, delimitou o objeto da tutela jurisdicional, assim como definiu os mecanismos jurídicos aptos a concretizar esta finalidade, dentre os quais se destaca o tombamento, tal como tipificado no $\$ 1^{\circ}$ do citado artigo.

Vislumbra-se, portanto, que o tombamento é apenas um dos diversos meios de proteção do patrimônio histórico e cultural brasileiro.

A priori, há que se ressaltar a origem histórica do termo, advinda do direito português, tal como já apontado no primeiro capítulo do presente trabalho e ratificado por Pietro (2011):

Empregando o vocábulo tombamento, o direito brasileiro seguiu a tradição do direito português, que utiliza a palavra tombar no sentido de registrar, inventariar, inscrever nos arquivos do Reino, guardados na Torre do Tombo. ${ }^{40}$

Relativamente ao conceito de tombamento, infere-se que se trata de um tipo específico de servidão administrativa, com a finalidade de preservar a história e a cultura nacionais.

Contudo, parcela da doutrina administrativa tende a considerar o tombamento como uma limitação administrativa à propriedade privada, e não como uma servidão, haja vista a sujeição do proprietário às restrições impostas pelo poder público.

Esta mesma doutrina aduz também que inexistiria, portanto, relação de direito real entre o poder estatal e o bem tombado, tal como nas servidões administrativas comuns.

Há ainda uma terceira posição, defendida por Carvalho Filho (2011), que entende o tombamento como um "instrumento especial de intervenção restritiva do Estado na propriedade privada, com fisionomia própria e inconfundível com as demais formas de intervenção". ${ }^{41}$

Desta forma, o conceito de tombamento se traduz na manifestação de vontade expressa da Administração Pública, que se funda na adequação da propriedade privada a sua função social, a qual é desvirtuada quando prejudicial à proteção ao patrimônio cultural, histórico e artístico, além de se fundamentar no interesse da coletividade na conservação dos bens, sejam eles móveis ou imóveis, públicos ou privados.

Por tais razões, o tombamento é um ato administrativo efetivado pelo Poder Público, com o fito de salvaguardar os bens de interesse da coletividade, tendo em vista a sua importância para histórica, artística, cultural

\footnotetext{
${ }^{39}$ CARVALHO FILHO, José dos Santos. Manual de Direito Administrativo. 24. ed. Rio de Janeiro: Lúmen Juris, 2011, p.793.

${ }^{40}$ MEIRELLES, 1989 apud PIETRO, Maria Sylvia Zanella Di. Direito Administrativo. 24. ed. São Paulo: Atlas, 201 1, p.91. vol.10, nº. 01, Rio de Janeiro, 2017.pp.95-126 
e paisagística. Sua efetivação ocorre por meio da aplicação da legislação constitucional e infraconstitucional atinentes.

O tombamento se perfaz por meio de sucessivos atos exarados no âmbito de processo administrativo iniciado pelo Poder Público, que culmina na inscrição do bem portador de referência histórica no livro do tombo, fase que encerra o processo e torna o bem passível da tutela jurisdicional.

Em linhas semelhantes, ensina Marinela (2011), que "a determinação de tombamento de um bem é resultado de um processo administrativo, isto é, uma sucessão de atos preparatórios e indispensáveis à validade do ato final, que culmina na inscrição no Livro do Tombo". ${ }^{2}$

Posto isso, depreende-se que o tombamento, assim como outros procedimentos da seara administrativa, demanda o perpassar de inúmeras fases procedimentais, bem como a efetivação de diversos atos sucessivos, que devem ser cronologicamente respeitados, sob pena de invalidade do ato final.

Tal como leciona Zandonade (2012), "o exame dos critérios preestabelecidos em lei no que tange ao ato administrativo de tombamento é essencial para que se possa identificar o campo típico da aplicação do instituto". ${ }^{43}$

Há que se realçar, contudo, que as fases procedimentais infra elencadas se aplicam exclusivamente à modalidade compulsória do tombamento, cujas etapas ocorrem sem a anuência do proprietário, isto é, com a "imposição unilateral do tombamento, seguida da notificação da entidade pública a cujo patrimônio pertence o bem atingido" ${ }^{44}$

Contrário sensu, o tombamento voluntário pode decorrer da solicitação do proprietário do bem, assim como da anuência deste quando da solicitação de tombamento pela administração pública, nos termos do artigo $7^{\circ}$, do Decreto-Lei n ${ }^{\circ} 25 / 37$.

Nesta modalidade de tombamento não subsiste qualquer controvérsia judicial entre o proprietário e a Administração Pública a ser discutida, realizando-se, portanto, de forma imediata após a constatação efetiva do relevante valor referencial do bem corpóreo.

Por fim, imperioso gizar que as regras atinentes ao tombamento a seguir expostas assumem o status de norma geral, visto que se encontram dispostas no bojo do Decreto-Lei n² $25 / 37$, voltadas, portanto, tão somente para a ordem jurídica federal.

"Não obstante, é certo que Estados, Municípios e Distrito Federal também dispõem de competência material para a proteção de bens portadores de valor cultural, de acordo com o art. 23, III, IV e V e com o art.30,

\footnotetext{
${ }^{41}$ CARVALHO FILHO, José dos Santos. Manual de Direito Administrativo. 24. ed. Rio de Janeiro: Lúmen Juris, 201 1, p.797.

${ }^{42}$ MARINELA, Fernanda. Direito Administrativo. 5. ed. Niteroi: Impetus, 2011, p.867.

${ }^{43}$ ZANDONADE, Adriana. O Tombamento à Luz da Constituição Federal de 1988. São Paulo: Malheiros, 2012, p.204.

${ }^{44}$ Ibid., p.225.
} 
IX, da Carta de 1988". ${ }^{45}$

A solicitação de tombamento é considerada com a etapa prévia do procedimento, que somente terá início após a efetivação do parecer técnico, no qual a Administração Pública identifica o valor cultural do bem a ser tombado. Posteriormente à elaboração do parecer técnico e sua aprovação, instaurar-se-á o processo de tombamento.

No que tange a legitimidade para solicitar o tombamento, verifica-se que qualquer cidadão, entidade, associação e/ou órgão destinado à preservação de bens de patente valor histórico, paisagístico ou cultural poderá fazê-lo, seja no âmbito municipal, estadual ou federal.

A ampla legitimidade para solicitar o tombamento advém das dicções do artigo 216, $\$ 1^{\circ}$, da Constituição Federal, segundo o qual é dever da comunidade colaborar com poder público na promoção e proteção ao patrimônio cultural brasileiro.

Apesar da abrangente legitimidade para solicitar a instauração do procedimento, é certo que na esfera federal as solicitações devem ser encaminhadas para a Presidência do IPHAN, para que sejam adotadas as cautelas de praxe.

No âmbito estadual, as solicitações serão encaminhadas ao órgão estadual responsável, tal como o IEPHA em Minas Gerais. Nos casos em que toca a esfera municipal as solicitações devem ser direcionadas à Municipalidade, para posterior elaboração do parecer técnico.

Por seu turno, importante vincar que juntamente com solicitação devem ser encaminhados todos os documentos pertinentes ao tombamento, dentre os quais se incluem fotografias, dados históricos e levantamentos arquitetônicos do bem, além das justificativa para o tombo, de forma a proporcionar elementos mínimos à análise quanto à pertinência e viabilidade da instauração do procedimento administrativo.

Finda a etapa preliminar, a diretoria do órgão analisará o pleito e os demais elementos probatórios carreados à solicitação, manifestando-se consecutivamente ao proponente.

Ato contínuo, deve ser emitido o parecer de tombamento, que entabulará o Estudo de Avaliação de Tombamento (EAT) que, por conseguinte, dará início ao transcorrer processual do tombamento.

Porém, tratando-se de bens públicos, cujo interesse cultural e arquitetônico seja patente, a autoridade pode determinar a inscrição do bem no livro do tombado imediatamente, com a posterior notificação das pessoas jurídicas de direito público.

Nesse rumo, nota-se que no caso do tombamento de bens público a ampla defesa é inviabilizada, tal como predisposto no artigo $5^{\circ}$, do Decreto-Lei n 25/37. Vejamos:

O tombamento dos bens pertencentes à União, aos Estados e aos Municípios se fará de

${ }^{45}$ ZANDONADE, Adriana. O Tombamento à Luz da Constituição Federal de 1988. São Paulo: Malheiros, 2012, p.95. 
ofício, por ordem do diretor do Serviço do Patrimônio Histórico e Artístico Nacional, mas deverá ser notificado à entidade a quem pertencer, ou sob cuja guarda estiver a coisa tombada, a fim de produzir os necessários efeitos. ${ }^{46}$

Não obstante a referida previsão legal, convém trazer à baila o posicionamento doutrinário mais recente quanto à temática.

A doutrina é uníssona em considerar o dispositivo acima elencado como inconstitucional, pois é clara violação do princípio do devido processo legal, sendo imprescindível assegurar a oportunidade de manifestação prévia do proprietário, mesmo em se tratando de pessoas jurídicas de direto público, "desde que não alcance bens pertencentes ao próprio Instituto do Patrimônio e Artístico Nacional/IPHAN" ${ }^{47}$

Por derradeiro, salienta-se que, é reservado ao proprietário o direito à impugnação do ato, abrindo-se, inclusive, oportunidade dos vizinhos contíguos ao imóvel se manifestarem, visto que a conclusão do processo administrativo também os obrigará a preservar o bem.

Encaminhada a solicitação à diretoria do órgão competente, bem como decorrida sua análise e emitida a manifestação ao proponente, por meio do Parecer de Tombamento favorável ao tombo, será procedida a realização do Estudo de Avaliação de Tombamento (EAT).

O Estudo de Avaliação de Tombamento deverá ser realizado pela divisão técnica da diretoria do órgão no qual o tombamento foi solicitado, sendo consecutivamente apresentado ao Conselho de Patrimônio, como por exemplo, o Conselho Estadual de Patrimônio (CONEP), integrante do IEPHA/MG.

O objetivo principal do EAT é verificar se o bem possui realmente valor histórico, cultural ou paisagístico que fundamente a intervenção na propriedade.

Concomitantemente, o Conselho de Patrimônio avaliará os requisitos de conveniência, oportunidade e pertinência de ser prosseguido o tombamento (mérito administrativo).

Posto isso, procedida à reunião do Conselho de Patrimônio e emitida decisão favorável ao prosseguimento do tombamento, será assegurado em ata o tombamento provisório do bem, o qual tem caráter preventivo e se assemelha ao tombamento definitivo no que concernem as limitações incidentes sobre o bem.

Desta forma, o tombamento provisório tem por finalidade preservar o bem até o trânsito em julgado da decisão definitiva, ou seja, tem caráter essencialmente cautelar, uma vez que há efetivo risco de perda do objeto da ação, haja vista a possível destruição do bem.

Por tais razões, assim como a medida definitiva, o tombamento cautelar contrapõe-se aos interesses da propriedade privada, visto que obriga o proprietário a tomar às medidas necessárias à conservação do bem. Entretanto, cuida-se de medida estritamente necessária para evitar a descaracterização do bem.

\footnotetext{
${ }^{46}$ BRASIL. Decreto-Lei no 25, de 30 de novembro de 1937. Organiza a proteção do patrimônio histórico e artístico nacional. Diário Oficial da República Federativa do Brasil, Rio de Janeiro, RJ, 6 dez. 1937. Disponível em: <http://www.planalto.gov.br/ccivil_03/decreto-lei/del0025.htm>. Acesso em: 20/06/14.
} 
Quanto aos efeitos do tombamento provisório, o artigo $10^{\circ}$, parágrafo único, do Decreto-Lei n $25 / 37$ dispõe que serão análogos aos do tombamento definitivo.

Procedida à elaboração do parecer técnico, com a devida individualização do bem, constatação de seu relevante valor histórico e cultural e apontadas as razões que justificam o tombamento, é imprescindível que o proprietário seja notificado para que, no prazo de 15 dias, ofereça sua anuência com o tombamento, ou impugne o ato, com a juntada das respectivas razões.

Nesse mesmo diapasão ratifica Zandonade (2012):

Presentes os requisitos da espécie, uma vez devidamente individualizado o bem, como a descrição de suas características e de sua localização, assim como apontadas as razões que justifiquem o tombamento, o proprietário deve ser notificado para, no prazo de 15 dias manifestar sua anuência ou, se for o caso, para oferecer impugnação. ${ }^{48}$

A imprescindibilidade da notificação do proprietário do bem reside não somente na aplicação do princípio da ampla defesa procedimental, mas também guarda relação direta com a produção antecipada dos efeitos do instituto em testilha, visto que propicia realização do tombamento provisório, garantindo a imediatidade da medida protecionista, tal como anteriormente elucidado neste trabalho e disposto no parágrafo único, do artigo $10^{\circ}$, do Decreto-Lei n ${ }^{\circ} 25 / 37$.

De outro bordo, infere-se que o supramencionado Decreto-Lei não disciplina os requisitos da notificação. Contudo, vê-se que a finalidade precípua é a ciência do proprietário sobre o processo que se inicia, reservando-lhe o direito à ampla defesa.

Sem embargo, a doutrina administrativista ensina que a notificação deve conter essencialmente quatro elementos, quais sejam, a identificação pormenorizada do bem, as razões que ensejaram o tombamento, indicação do número de distribuição dos autos, o endereço em que se encontram os respectivos autos e, por fim, o prazo para apresentação da anuência ou impugnação (15 dias).

No que concerne à forma em que se dará a notificação, têm-se que esta deve ocorrer preferencialmente de forma pessoal, e em casos excepcionais com a publicação de edital, nos termos do artigo 26 , parágrafos $3^{\circ}$ e $4^{\circ}$, da Lei no 9.784/99.

É de fundamental relevância que os vizinhos dos imóveis contíguos ao bem também sejam notificados, vez que as obrigações atreladas ao bem corpóreo também os afetará, mesmo que indiretamente.

Procedida a notificação, com a expressa concordância do proprietário, ou a ausência de manifestação no prazo de 15 dias, realizar-se-á o tombamento voluntário, consoante expresso no artigo $7^{\circ}$, do Decreto-Lei ${ }^{\circ}$ $25 / 37$.

Nessa monta, de acordo com o item número 2 do artigo $9^{\circ}$ do mesmo decreto, quando ausente o

${ }^{47}$ ZANDONADE, Adriana. O Tombamento à Luz da Constituição Federal de 1988. São Paulo: Malheiros, 2012, p.226.

${ }^{48}$ Ibid., p.227. 
assentimento expresso, bem como não interposta à impugnação, a inscrição no livro do tombo estaria autorizada e realizar-se-ia por simples despacho.

Entretanto, por força do Decreto-Lei $n^{\circ} 3.866 / 41$, a decisão administrativa que determina o tombamento é passível de recurso administrativo, em respeito ao devido processo legal. "Acontece que a competência para decidir acerca da aplicação, ou não, do tombamento foi conferida em caráter exclusivo ao Conselho Consultivo do Patrimônio Cultural”. ${ }^{9}$

Todavia, o Conselho Consultivo do Patrimônio Cultural é órgão meramente consultivo, ou seja, foge à relação hierárquica, motivo pelo qual não poderá julgar o recurso.

Por tais razões, restou incumbido ao Presidente da República a competência para cancelar o tombamento, seja de ofício ou mediante recurso, nos termos do artigo único da citada legislação:

Artigo único. O Presidente da República, atendendo a motivos de interesse público, poderá determinar de ofício ou em grau de recurso, interposto pôr qualquer legítimo interessado, seja cancelado o tombamento de bens pertencentes à União, aos Estados, aos municípios ou a pessoas naturais ou jurídicas de direito privado, feito no Serviço do Patrimônio Histórico e Artístico Nacional, de acordo com o decreto-lei no 25 , de 30 de novembro de 1937.50

Porém, há que se ressalvar, que à época da edição do Decreto regulador, a competência para a realização do Tombamento era incumbida ao Serviço do Patrimônio Histórico e Artístico Nacional, órgão integrante da Administração Pública direta.

Diversamente, na atualidade a competência atinente ao tombamento pertence ao IPHAN, que é entidade autárquica, ou seja, integrante da Administração Pública indireta, tratando-se, portanto, de um recurso hierárquico impróprio, devendo ser interpretado de forma restritiva e, consequentemente, aplicável apenas para as hipóteses de cancelamento do tombo.

Nessa vereda, perpassadas as fases acima elencadas, o processo será encaminhado ao conselho consultivo responsável pelo tombo, para que seja analisado o mérito administrativo, materializado pelos critérios de conveniência (elemento objeto) e oportunidade (elemento motivo) da Administração Pública, comumente denominada como discricionariedade administrativa.

A discricionariedade é o meio colocado à disposição da Administração Pública para atentar os interesses públicos, sem que ocorram desvios de poder ou finalidade, que poderão ser reconhecidos e, oportunamente sanados pela própria Administração (poder de autotutela), ou pelo Poder Judiciário.

Convém notar, outrossim, que procedida a análise dos critérios de conveniência e oportunidade pelo conselho consultivo do órgão de preservação, exarado por meio de parecer, a decisão deverá ser homologada pelo titular da pasta da cultura, encerrando, pois, a fase deliberativa.

\footnotetext{
${ }^{49}$ Ibid., p.232.

${ }^{50}$ BRASIL. Decreto-Lei no 3.866, de 29 de novembro de 1941. Dispõe sobre o tombamento de bens no Serviço do Patrimônio Histórico e Artístico Nacional. Diário Oficial da República Federativa do Brasil, Rio de Janeiro, RJ, 31 dez. 1941. Disponível em: vol.10, nº. 01, Rio de Janeiro, 2017.pp.95-126 
Na definição de Mello (2012), homologação é "o ato vinculado pelo qual a Administração concorda com ato jurídico já praticado, uma vez verificada a consonância dele com os requisitos condicionadores de sua válida emissão". ${ }^{51}$

Por seu turno, é função do Ministério do Estado da Cultura verificar se o processo de tombamento foi realizado com as regularidades de praxe, homologando-o, obrigatoriamente, quando respeitados os parâmetros legais. Conforme disposto na Lei n 6.292/75.

Verificada a existência de vício de legalidade o Ministério de Estado da Educação de Cultura convalidará o ato ou, caso seja possível, a convalidação deverá invalidar o processo, podendo, inclusive, preservar atos não viciados.

Por tais razões, de um modo geral, infere-se que para com o perpassar da obrigação de notificar as pessoas, sejam elas físicas ou jurídicas, atingidas direta e indiretamente pelo processo que se conclui, prossegue-se para a fase consultiva e deliberativa, concretizada por meio do parecer do Conselho Consultivo do Patrimônio Cultural e homologação do Ministério da Cultura, as quais dão forma e efetivam o caráter protecionista e estatal da medida, concluindo, enfim, a execução dos atos materiais pertinentes ao processo de tombamento.

Contudo, salienta-se, por fim, que o caráter jurisdicional da medida só será ultimado com o registro do bem referencial em um dos quatro livros do tombo.

Em arremate, para que haja efetividade jurídica e, consequentemente, que os deveres exarados por meio do tombo sejam validados, assim como para que o processo administrativo de tombamento se dê por concluso, é imprescindível o registro do bem tombado em um dos quatro livros do tombo.

Convém salientar que existem quatro livros do tombo, quais sejam, a) livro do tombo arqueológico, etnográfico e paisagístico (destinado às categorias de arte arqueológica, etnográfica, ameríndia e popular, bem assim os monumentos naturais); b) livro do tombo histórico (proposto a salvaguardar os bens de interesses histórico e obras de arte histórica); c) livro do tombo das belas artes (designado à proteção das coisas de arte erudita estadual, nacional ou estrangeira); d) livro do tombo das artes aplicadas (talhado para as obras que se incluírem na categoria das Artes Aplicadas, sejam elas nacionais ou estrangeiras), conforme enunciado no artigo $4^{\circ}$, itens 1 a 4, do Decreto-Lei n 25/37.

Nesse sentido, enuncia Marinela (2011):

Por fim, o tombamento somente se torna definitivo com o registro em um dos Livros do Tombo. O Decreto-Lei 25/37 definiu, em seu art. $4^{\circ}$, os quatro Livros do Tombo: Livro do Tombo Arqueológico, Etnográfico e Paisagístico; das Belas Artes; das Artes Aplicadas; Histórico. ${ }^{52}$

<http://www.planalto.gov.br/ccivil_03/decreto-lei/1937-1946/Del3866.htm æ. Acesso em: 14/07/14.

${ }^{51}$ MELLO, Celso Antônio Bandeira de, apud ZANDONADE, Adriana. O Tombamento à Luz da Constituição Federal de 1988. São Paulo: Malheiros, 2012, p.231.

${ }^{52}$ MARINELA, Fernanda. Direito Administrativo. 5.ed. Niterói: Impetus, 2011, p.868. 
Anote-se ainda que, no Livro do Tombo serão minutados os eventos fundamentais e de maior relevância do bem, tais como, a vida e história deste, suas principais atividades e acontecimentos que o levaram a se tornar ponto referencial da cultura e/ou história para a sociedade, etc.

Sob a mesma ótica, vê-se que o Livro do Tombo servirá também como documento histórico, utilizado inclusive na elaboração de relatórios anuais das atividades realizadas no bem, para fins de fiscalização e prestação de contas.

Infere-se também que, se o tombamento for realizado sobre bens imóveis, estes dependerão ainda do Registro de Imóveis, isto é, deverá ser feita a averbação em cartório de registro de imóveis onde esse bem estiver registrado.

Relativamente ao âmbito federal e ao tombamento realizado pelo IPHAN, denota-se que os livros do tombo ficam armazenados no acervo da Biblioteca Noronha Santos em homenagem ao historiador Francisco Agenor Noronha Santos, colaborador assíduo da instituição.

Nesse passo, as ações de registro no Livro do Tombo voltam-se para a identificação, documentação, restauração, conservação, preservação, fiscalização e difusão dos bens tombados, tornando tais processos mais céleres e eficazes, garantindo, pois, maior proteção jurídica da medida.

\section{CONCLUSÃO}

A preservação do patrimônio histórico, artístico e cultural tem importância social fundamental, além de possuir grande valia para a construção da identidade entre os indivíduos ou grupo de pessoas para com a história que lhes é de alguma forma, simbólica e notável.

Do mesmo modo, é certo que a conservação destes bens de especial relevância proporciona a comunhão de valores emanados por cada um dos indivíduos com os demais membros da sociedade, que ainda se encontram alheios a essa conexão preexistente.

Sob esse prisma, denota-se que a intervenção do Estado na propriedade privada, por meio do tombamento, não tem por escopo turbar os interesses do cidadão, proprietário do bem e detentor de interesses econômicos, mas sim preservar os interesses da sociedade em toda sua estratificação, tendo em vista que o patrimônio cultural é, genericamente, um direito transindividual e pertence a todos sem qualquer discriminação ou condição preordenada, demandando, por tal razão a tutela estatal, ainda que em detrimento dos interesses do particular.

No entanto, compreender a importância de se perpetuar vividamente a memória cultural e histórica revela-se tarefa muitas vezes complexa para a sociedade civil, uma vez que, quem se vêm na iminência das restrições e obrigações impostas pelo tombamento teme pela desvalorização econômica do bem e/ou pela falta 
de amparo do Estado na manutenção das características do imóvel que o tornaram essencial para coletividade.

Nessa toada, conforme exaustivamente explanado, em antagonismo às infundadas teses de depreciação econômica do imóvel tombado, cita-se o exemplo da "Confeitaria Colombo", situada no Rio de Janeiro, que embora tenha sido tombada pelo poder público em 1983, é rentável e próspera economicamente, sem que seja perdida toda a história e a beleza arquitetônica por ela emanada.

Oportuno evocar também o exemplo da "Casa das Rosas", situada em São Paulo, na Avenida Paulista, centro nevrálgico da econômica brasileira e símbolo do capitalismo moderno, que foi edificada em 1935 e, mesmo circunvalada de construções desmesuradas de história e belezas arquitetônicas ou paisagísticas, sobrevive incansavelmente à ambição insaciável por empreitadas lucrativas.

Assim, conclui-se que o tombamento é normalmente associado à depreciação econômica do imóvel passível de tutela estatal. Porém, conforme já demonstrado, tal cooptação não é verdadeira, visto que existem diversos incentivos fiscais e/ou econômicos aos proprietários do imóvel, assim como assinala-se que inexiste turbação na propriedade do bem, que normalmente se mantém intacta, sob pena de caracterizar a desapropriação indireta.

De mais a mais, não resta descartada a possibilidade de indenização pecuniária pelo tombamento.

Em arremate, vê-se que a despreocupação da grande parcela populacional com a difusão da própria história, arte e cultura para as futuras gerações é patente, o que acaba por gerar devastador desapego e o esquecimento de momentos e experiências que foram vividos de forma única em determinado momento, as quais deverão ser copiosamente reconstruídas com o perpassar dos anos.

\title{
PROTECTION OF HISTORICAL, CULTURAL AND ARTISTIC PATRIMONY AND THE INSTITUTE OF “TOMBAMENTO”
}

\begin{abstract}
The protection of historical, cultural and artistic heritage is of fundamental importance for the community and for future generations, as it allows the stories and cultural experiences are perpetuated in time, serving us the foundation to build the present, without restore the past. In this light, we see that it is not for only the judicial or legislative caring for the theme, but also society, in collaboration with the government, as registered the Federal Constitution. The theme shows its relevance when contrasted with other constitutional relief institutes, such as the property, which is mitigated front of the story to be safeguarded. Thus, it is essential to discuss the historical and conceptual aspects the theme, starting with comparative law, especially the Portuguese and French, in view of the bourgeois revolutions that opened the judicial protection of the story. Also necessary to carry out an analysis of the guiding principles of administrative tipping, they are basic norms of legal science, basing it on the construction of other institutes. Moreover, fundamental analysis of the forms of action of the Public Ministry and other bodies of public administration, as well as the minutiae of tipping process in order to obtain a critical and thoughtful analysis of the subject.
\end{abstract}


Keywords: Tipping; Cultural Heritage and Artistic; Judicial Protection; Protection; Decree Law 25/37; Protection Mechanisms.

\section{REFERÊNCIAS BIBLIOGRÁFICAS}

BRASIL, Constituição da República dos Estados Unidos do Brasil, de 24 de fevereiro de 1891. Diário Oficial da República Federativa do Brasil, Rio de Janeiro, RJ, 24 fev. 1891. Disponível em: <http://www.planalto.gov.br/ccivil_03/constituicao/constituicao91.htm>. Acesso em: 05/03/14.

Constituição da República dos Estados Unidos do Brasil, de 16 de julho de 1934. Diário Oficial da República Federativa do Brasil, Rio de Janeiro, RJ, 16 jul. 1934 - Suplemento e republicado em 19 dez. 1935. Disponível em: <http://www.planalto.gov.br/ccivil_03/constituicao/constituicao34.htm>. Acesso em: 06/03/14.

Constituição da República dos Estados Unidos do Brasil, de 10 de novembro de 1937. Leis Constitucionais. Diário Oficial da República Federativa do Brasil, Rio de Janeiro, RJ, 10 nov. 1937, republicada em 11 nov. 1937, 18 nov. 1937 e 19 nov. 1937. Disponível em: <http://www.planalto.gov.br/ccivil_03/constituicao/constituicao37.htm>. Acesso em: 08/03/14.

Constituição da República Federativa do Brasil de 1988, de 5 de outubro de 1988. Diário Oficial da República Federativa do Brasil, Brasília, DF, 5 out. 1988. Disponível em: <http://www.planalto.gov.br/ccivil_03/constituicao/constituicao.htm>. Acesso em: 10/03/14.

Decreto-Lei No 25, de 30 de novembro de 1937. Organiza a proteção do patrimônio histórico e artístico nacional. Diário Oficial da República Federativa do Brasil, Rio de Janeiro, RJ, 6 dez. 1937. Disponível em: $<$ http://www.planalto.gov.br/ccivil_03/decreto-lei/del0025.htm>. Acesso em: 14/03/14.

Decreto-Lei No 3.866, de 29 de novembro de 1941. Dispõe sobre o tombamento de bens no Serviço do Patrimônio Histórico e Artístico Nacional. Diário Oficial da República Federativa do Brasil, Rio de Janeiro, RJ, 31 dez. 1941. Disponível em: <http://www.planalto.gov.br/ccivil_03/decreto-lei/1937-1946/Del3866.htm>. Acesso em: 14/07/14.

Decreto No 5.520, de 24 de agosto de 2005. Institui o Sistema Federal de Cultura - SFC e dispõe sobre a composição e o funcionamento do Conselho Nacional de Política Cultural - CNPC do Ministério da Cultura, e dá outras providências. Diário Oficial da República Federativa do Brasil, Brasília, BR, 25 ag. 2005. Disponível em: <http://www.planalto.gov.br/ccivil_03/_ato2004-2006/2005/Decreto/D5520.htm>. Acesso em: 14/07/14.

Emenda Constitucional No $19, \bar{d}$ de 4 de junho de 1998. Modifica o regime e dispõe sobre princípios e normas da Administração Pública, servidores e agentes políticos, controle de despesas e finanças públicas e custeio de atividades a cargo do Distrito Federal, e dá outras providências. Diário Oficial da República Federativa do Brasil, Brasília, DF, 5 jun. $1998 . \quad$ Disponível em: <http://www.planalto.gov.br/ccivil_03/constituicao/Emendas/Emc/emc19.htm>. Acesso em: 03/04/14.

Instituto Brasileiro de Geografia e Estatística. Brasil: 500 anos de povoamento. Rio de Janeiro, 2000. Disponível em: <http://brasil500anos.bge.gov.br/territorio-brasileiro-e-povoamento/historia-indigena/osnumeros-da-populacao-indigena $>$. Acesso em: 01/09/14.

Lei № 378, de 13 de janeiro de 1937. Dá nova, organização ao Ministério da Educação e Saúde Pública. Senado Federal. Secretaria de Informação Legislativa. Rio de Janeiro, RJ, 13 jan. 1937. Disponível em: $<$ http://legis.senado.leg.br/legislacao/ListaPublicacoes.action?id=102716\&tipoDocumento=LEI\&tipoTexto=P $\mathrm{UB}>$. Acesso em: 13/06/14.

Lei No 4.717, de 29 de junho de 1965. Regula a ação popular. Diário Oficial da República Federativa do Brasil, Brasília, DF, 5 jun. 1965 e republicado no DOU de 8 abr. 1974. Disponível em: <http://www.planalto.gov.br/ccivil_03/leis/14717.htm>.Acesso em: 13/06/14.

Lei No 6.292, de 15 de dezembro de 1975. Dispõe sobre o tombamento de bens no Instituto do 
Patrimônio Histórico e Artístico Nacional (IPHAN). Diário Oficial da República Federativa do Brasil, Brasília, DF, 16 dez. 1975. Disponível em: <http://portal.iphan.gov.br/portal/baixaFcdAnexo.do?id=226>. Acesso em: $15 / 07 / 14$.

Lei No 7.347, de 24 de julho de 1985. Disciplina a ação civil pública de responsabilidade por danos causados ao meio-ambiente, ao consumidor, a bens e direitos de valor artístico, estético, histórico, turístico e paisagístico (Vetado) e dá outras providências. Diário Oficial da República Federativa do Brasil, Brasília, DF, 25 jul. 1985. Disponível em: <http://www.planalto.gov.br/ccivil_03/leis/17347orig.htm>. Acesso em: 05/05/14.

Lei No 8.078, de 11 de setembro de 1990. Dispõe sobre a proteção do consumidor e dá outras providências. Diário Oficial da República Federativa do Brasil, Brasília, DF, 12 set. 1990 - Edição extra e retificado em 10 jan. 2007. Disponível em: <http://www.planalto.gov.br/ccivil_03/leis/18078.htm>. Acesso em: 02/06/14.

Lei № 8.313, de 23 de dezembro de 1991. Restabelece princípios da Lei nº 7.505, de 2 de julho de 1986, institui o Programa Nacional de Apoio à Cultura (Pronac) e dá outras providências. Diário Oficial da República Federativa do Brasil, Brasília, DF, 24 dez. 1991. Disponível em: <http://www.planalto.gov.br/ccivil_03/leis/18313cons.htm>.Acesso em:02/06/14.

Lei № 9.784, de 29 de janeiro de 1999. Regula o processo administrativo no âmbito da Administração Pública Federal. Diário Oficial da República Federativa do Brasil, Brasília, DF, 1 fev. 1999 e retificado em 11 mar. 1999. Disponível em: <http://www.planalto.gov.br/ccivil_03/leis/19784.htm>. Acesso em: 04/07/14.

Lei No 10.257, de 10 de julho de 2001. Regulamenta os arts. 182 e 183 da Constituição Federal, estabelece diretrizes gerais da política urbana e dá outras providências. Diário Oficial da República Federativa do Brasil, Brasília, DF, 11 jul. 2001 e retificado em 17 jul. 2001. Disponível em: <http://www.planalto.gov.br/ccivil_03/leis/leis_2001/110257.htm>. Acesso em: 19/05/14.

Lei No 10.406, de 10 de janeiro de 2002. Institui o Código Civil. Diário Oficial da República Federativa do Brasil, Brasília, DF, 11 jan. 2002. Disponível em: <http://www.planalto.gov.br/ccivil_03/leis/2002/110406.htm>. Acesso em: 24/03/14.

Ministério da Cultura. O CNPC (Conselho Nacional de Política Cultural). Brasília, 2013. Disponível em: <http://www.cultura.gov.br/cnpc/o-cnpc>. Acesso em: 30/05/14.

CARVALHO FILHO, José dos Santos. Manual de Direito Administrativo. 24. ed. Rio de Janeiro: Lúmen Juris, $2011.1157 \mathrm{p}$.

DELGADO, Maurício Godinho. Princípios de direito individual e coletivo do trabalho. Rev. TST. Brasília, DF, v. 75, n. $\quad 3, \quad 2009, \quad 34 \mathrm{p}$. Disponível em: <http://www.tst.jus.br/documents/1295387/1312882/1.+Os+princ\%C3\%ADpios+na+estrutura+do+Direito> .Acesso em: 10/04/14.

MANCUSO, Rodolfo de Camargo. Ação Civil Pública: em defesa do meio ambiente, do patrimônio cultural e dos consumidores: Lei 7.347/85 e legislação complementar. 10 ed., São Paulo: Revista dos Tribunais, 2007, p.112. Disponível em: <http://pt.scribd.com/doc/69645725/MANCUSO-Rodolfo-de-Camargo-Acao-CivilPublica-10\%C2\%AA-Edicao-2007>. Acesso em: 15/06/14.

MARINELA, Fernanda. Direito Administrativo. 5. ed. Niterói: Impetus, 2011. 1106 p.

MAZZILLI, Hugo Nigro. Manual do promotor de Justiça. 2. ed. São Paulo: Saraiva, 1991. 663 p.

MENDES, Gilmar Ferreira; BRANCO, Paulo Gustavo Gonet. Curso de Direito Constitucional. 7. ed. São Paulo: Saraiva, 2012.1592p.

MINAS GERAIS, Constituição do Estado de Minas Gerais (1989), 15 ed. Belo Horizonte: Assembleia vol.10, nº. 01, Rio de Janeiro, 2017.pp. 95-126 
Legislativa do Estado de Minas Gerais, 2013. 279p. Disponível em: <http://www.tce.mg.gov.br/IMG/Legislacao/legiscont/Constitui\%C3\%A7\%C3\%A30\%20Estadual.pdf>. Acesso em: 08/05/14.

Instituto Estadual do Patrimônio Histórico e Artístico de Minas Gerais (IEPHA). Relação de Bem/s Protegidos em Minas Gerais (2012). Disponível em: <www.iepha.mg.gov.br/ >. Acesso em: 05/08/14.

Lei No 18.030, de 12 de janeiro de 2009 (MG de 13/01/2009). Dispõe sobre a distribuição da parcela da receita do produto da Arrecadação do ICMS pertencente aos municípios. Disponível em: <http://www.fazenda.mg.gov.br/empresas/legislacao_tributaria/leis/2009/118030_2009.htm>. Acesso em: $30 / 04 / 14$.

MIRANDA, Marcos Paulo de Souza. Benefícios para proprietários de bens tombados. Jus Navigandi, Teresina, PI, ano 15, n. 2667, 2010. Disponível em: <http://jus.com.br/artigos/17636/beneficios-para-proprietarios-de-benstombados>. Acesso em: 08/06/14.

OLMO, Manolo Del. Tombamento: aspectos jurídicos. Jus Navigandi, Teresina, PI, ano 5, n. 48, 2000. Disponível em: <http://jus.com.br/artigos/486/tombamento>. Acesso em: 26/04/14.

PEREIRA, Caio Mário da Silva. Instituições de Direito Civil, Direitos Reais. 21. ed. Rio de Janeiro: Forense, vol. IV, p. 75, 2012.

PIETRO, Maria Sylvia Zanella Di. Direito Administrativo. 24. ed. São Paulo: Atlas, 2011.497p.

REZENDE, Renato Teixeira; LOPO, Fabrício Costa. MINISTÉRIO PÚBLICO DO ESTADO DE MINAS GERAIS. Ação Civil Pública - Curadoria de Defesa do Patrimônio Cultural, Frutal, 2013. 53p.

RIO GRANDE DO SUL, Instituto do Patrimônio Histórico e Artístico do Estado (IPHAE). O significado da palavra tombamento. Disponível em: $<$ http:/ /www.iphae.rs.gov.br/Main.php?do=noticiasDetalhesAc\&item=37302 >. Acesso em: 02/09/14.

SÃO PAULO (SP), Prefeitura, Secretaria Municipal de Cultura. Lei de Incentivo Fiscal - Lei Municipal No 10.923, de 30 de dezembro de 1990. Dispóe sobre incentivo fiscal para a realização de projetos culturais, no âmbito do Município de São Paulo. Disponível em: <http://www.prefeitura.sp.gov.br/cidade/secretarias/cultura/lei_de_incentivo/index.php?p=6>. Acesso em: $10 / 07 / 14$.

SILVA, Marcus Flávio Alexandre Da. A política de incentivo à cultura no Ceará a partir da Lei Jereissati. 2005. 158 p. Dissertação (Mestrado Acadêmico em Políticas Públicas e Sociedade) - Universidade Estadual do Ceará, Centro de Estudos Sociais Aplicados. Fortaleza, Ceará, 2005. Disponível em: $<$ http://www.uece.br/politicasuece/index.php/arquivos/doc_view/62 marcosflavioalexandredasilva 1?tmpl=co mponent\&format=raw $>$. Acesso em: 10/05/14.

TAVARES, André Ramos. Curso de Direito Constitucional. 8. ed. São Paulo: Saraiva, 2010, p.1327.

ZANDONADE, Adriana. O Tombamento à Luz da Constituição Federal de 1988. São Paulo: Malheiros, 2012. 260p.

Trabalho enviado em 18 de junho de 2016.

Aceito em 15 de setembro de 2016. 